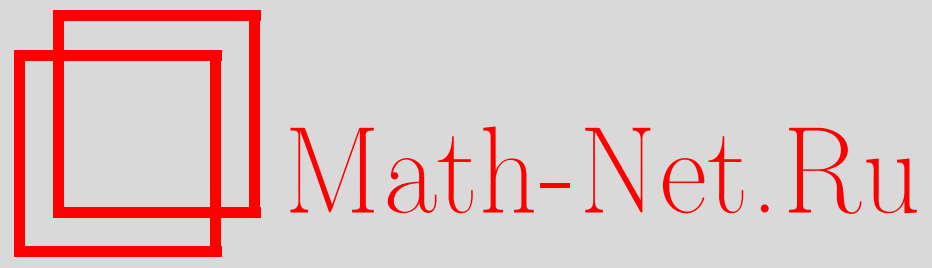

И. А. Ибрагимов, Ш. Шарахметов, Письмо в редакцию, Теория вероятн. и ее примен., 2002, том 47, выпуск 1, 204

DOI: https://doi.org/10.4213/tvp3530

Использование Общероссийского математического портала MathNet.Ru подразумевает, что вы прочитали и согласны с пользовательским соглашением

http://www . mathnet.ru/rus/agreement

Параметры загрузки:

IP : 3.89 .197 .203

26 апреля 2023 г., 14:32:18

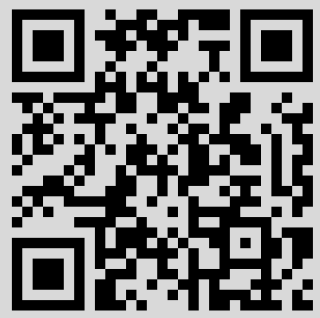


пределение агрегированных страховых выплат, принщишы расчета перестраховочных премий.

В пяти приложениях собраны сведения из теории восстановления (прил. 1), из теории Винера-Хопфа (прил. 2), сведения о матричныг экспонентах (прил. 3), сведения из линейной алгебры (прил. 4) и сведения о распределениях фазового перехода (прил. 5).

Список литературы содержит 384 наименования. Краткие историко-библиографические справки приведены к большинству разделов книги. Это делает книгу полезным справочным пособием в океане журнальныг статей, посвященных различным вопросам, примыкающим к проблематике вероятностей разорения.

Книга содержит богатый фактический материал, в ней содержатся постановки продиктованных практикой сложных математических задач. $\mathrm{K}$ достоинствам книги следует отнести также то, что она написана на основе лекций и в расчете на использование при подготовке курсов лекций о вероятностях разорения для студентов университетов математических специальностей.

В. К. Малиновский

\section{Письмо в редакцию}

В нашей статье «Точная константа в неравенстве Розенталя для случайных величин с нулевым средним» («Теория вероятн. и ее примен.», 2001, т. 46, в. 1, c. 134-138) вместо ссылки [11] (с. 134, строка 5 снизу) следует читать [18], вместо [2]-[11] (с. 134, строка 7 снизу) следует читать [2]-[11], [18]. В списке литературы на с. 138 под номером [18] должна быть ссылка на работу Figiel T., Hitczenko P., Johnson W.B., Schechtman G., Zinn J. Extremal properties of Rademacher functions with applications to the Khintchine and Rosenthal inequalities. - Trans. Amer. Math. Soc., 1997, v. 349, p. 997-1027. 